\title{
GREECE
}

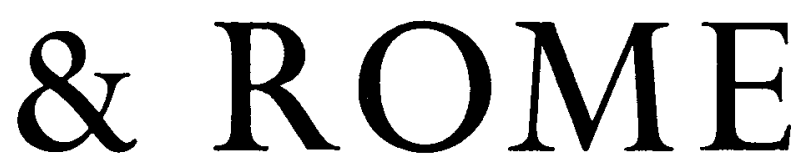

SECOND SERIES - VOLUME XVIII - I97I

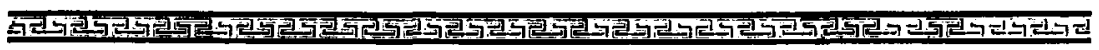

EDITORS

E. R. A. SEWTER

A. C. F. VERITY

Bristol Grammar School

P. WALCOT

University College Cardiff

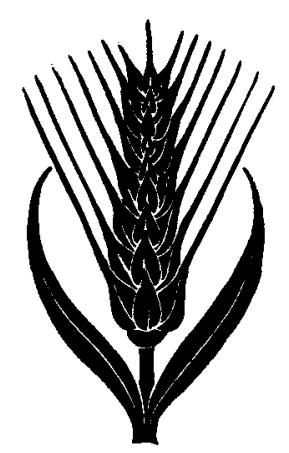

OXFORD - AT THE CLARENDON PRESS

PUBLISHED FOR THE CLASSICAL ASSOCIATION 
Oxford University Press, Ely House, London W.I

GLASGOW NEW YORK TORONTO MBLBOURNE WELLINGTON

CAPB TOWN SALISBURY IBADAN NAIROBI DAR ES SAALAM LUSAKA ADDIS ABABA

BOMBAY CALCUTTA MADRAS KARACHI LAHORE DACCA

KUALA LUMPUR SINGAPORE HONG KONG TOKYO

(C) OXFORD UNIVERSITY PRESS I 97 I

PRINTED IN GREAT BRITAIN AT THE UNIVERSITY PRESS, OXEORD BY VIVIAN RIDLER, PRINTER TO THE UNIVERSITY 


\title{
CONTENTS
}

\author{
NUMBER I, APRIL
}

LUCRETIUS AND HIS MESSAGE: A STUDY IN THE PROLOGUES OF THE DE RERUM NATURA A. S. Cox I VERSION

THE CONTINUITY OF HELLENISM

G. M. Lee I7

IGNOSCAS PETIMUS, VACERRA

MONASTIC CORRUPTION

George Thomson $\quad 18$

R. G. C. Levens 30

VERSION

R. M. Ogilvie 32

ARISTOPHANIC AND OTHER AUDIENCES

ODYSSEAN ECHOES IN PROPERTIUS IV. 8

THE TROJAN HORSE IN CLASSICAL ART

L. W. de Silva 34

P. Walcot 35

S. Evans 51

THE SILK TRADE BETWEEN CHINA AND THE ROMAN

EMPIRE AT ITS HEIGHT, CIRCA A.D. 90-130 $\mathcal{F}$. Thorley $7 \mathrm{r}$ NOTES ON CONTRIBUTORS

SOME ODYSSEAN SIMILES

Anthony $\mathcal{F}$. Podlecki $8 \mathbf{r}$

THE BIRTHPLACES OF LATIN WRITERS

LUCRETIUS V. I442

BRIEF REVIEWS

W. F. Watts 91

Martin F. Smith 102

BOOKS RECEIVED

E. R. A.S. 104

114

NUMBER 2, OCTOBER

VALE

HERODAS AND THE KITCHEN SINK

CICERO'S PHILARCHIA AND MARIUS

THE LARGE HOUSE AT DYSTOS IN EUBOEA

VERSION

WHO WERE THE AMAZONS?

NOTES ON CONTRIBUTORS

WAS CICERO AWARE OF NATURAL BEAUTY? THE CYCLOPS OF EURIPIDES

'CLASSICS IN THE CURRICULUM'

FORM AND IRONY IN CATULLUS XLV
T. W. M. II9

W. Geoffrey Arnott $12 \mathrm{I}$

Gerard B. Lavery 133

F. $V$. Luce 143

M. Hellewell 149

K. $A$. Bisset 150

7. C. Davies 152

R. G. Ussher 166

B. W. K. $\quad 179$

David Singleton 180

F. F. G. Gornall 188

TIME'?

THE CHANGE OF PLAN IN THE DOLONEIA THUCYDIDES AND THE USES OF HISTORY A LETTER FROM AUGUSTUS TO TIBERIUS VERSION

D. M. Gaunt Fohn Percival

R. Shaw-Smith G. M. Lee 214

SENECA'S HERCULES OETAEUS: A STOIC INTER-

PRETATION OF THE GREEK MYTH

REVIEW

BRIEF REVIEWS

BOOKS RECEIVED
C. P. B. Sewter

E. R. A. Sewter
Christine $M$. King 


\section{INDEX OF REVIEWS}

Anderson, J. K., Military Theory and Practice in the Age of Xenophon, 106

Anderson, Warren, Theophrastus, 224

Ashby, Thomas, The Roman Campagna in Classical Times, 112

Aström, Paul, The Thread of Ariadne, 112

Bailey, D. R. Shackleton, Cicero's Letters to Atticus (Index), 225

Balsdon, J. P. V. D., Rome: Story of an Empire, 229

Bandinelli, Ranuccio Bianchi, Rome: The Centre of Power, II2; Rome: The Late Empire, 23 I

Birley, Robin, Vindolanda: The Nature of the Evidence, 233

Bishop, Morris, A Classical Storybook, 105

Bray, Warwick, A Dictionary of Archaeo$\log y, \mathrm{I}_{\mathrm{I}} \mathrm{I}$

Brink, C. O., Horace on Poetry, 236.

Brown, Peter, The World of Late Antiquity, 229

Brunt, P. A., Social Conflict in the Roman Republic, 229

Bullitt, Orville H., Search for Sybaris, 232

Clairmont, Christoph, Gravestone and Epigram, 109

Crawford, Dorothy, Kerkeosiris, 230

Cunliffe, Barry, Fishbourne, 232; Roman Bath Discovered, 232

Cüppers, Heinz, Der Trierer Römerbrücken, 109

Dicks, D. R., Early Greek Astronomy to Aristotle, 233

Diggle, James, Euripides: Phaethon, 105

Dorey, T. A. (ed.), Erasmus, 105

Dudley, Donald, The Romans, 108

Duff, J. D., Yuvenal: Satires, 225

Edwards, I. E. S. (ed.), Cambridge Ancient History, vol. i, pt. i, 227

Ferguson, John, Socrates, 106; Religions of the Roman Empire, 233

Gadd, C. J. (ed.), Cambridge Ancient History, vol. i, pt. i, 227

Grant, Michael, The Roman Forum, r07; Nero, 107

Green, Peter, The Year of Salamis, 105 ; Alexander the Great, 106 ; Armada from Athens, 228

Grimal, Pierre, Guide de l'Etudiant latiniste, 226

Gullberg, Elsa, The Thread of Ariadne, I 12 Hale, William H., Ancient Greece, 227
Hammond, N. G. L. (ed.), The Oxford Classical Dictionary, I о; Cambridge Ancient History, vol. i, pt. i, 227

Hardt, Fondation, Lucain, ro4

Hazan, Fernand, Dictionary of Ancient Greek Civilization, I I I

Hölscher, Tonio, Victoria Romana, I 10

Hopper, R. J., The Acropolis, 23 I

Jones, A. H. M., History of Rome through the Fifth Century, 108; Augustus, 228; The Prosopography of the Later Roman Empire, 236

Kenyon, Kathleen, Palestine in the Time of the Eighteenth Dynasty, 227

Lacey, W. K., Res Publica, I07

Martindale, J. R., The Prosopography of the Later Roman Empire, 236

Mellersh, H. E. L., The Destruction of Knossos, 227

Menzel, Heinz, Antike Lampen, 109

Morris, J., The Prosopography of the Later Roman Empire, 236

Norcio, Giuseppe, Cicerone: Opere retoriche $I, \mathrm{IO} 4$

Otis, Brooks, Ovid as an Epic Poet, 225

Parry, Milman, The Making of Homeric Verse, 226

Payne, Robert, Ancient Rome, 228

Pendlebury, J. D. S., The Archaeology of Crete, 231

Plescia, Joseph, The Oath and Perjury in Ancient Greece, I I 3

Prückner, Helmut, Die lokrischen Tonreliefs, I Io

Putnam, Michael, Virgil's Pastoral Art, IO4

Quinn, K., Catullus, 225

Radice, Betty, Who's Who in the Ancient World, 234

Raubitschek, Isabelle, The Hearst Hillsborough Vases, 109

Richter, Gisela, Perspective in Greek and Roman Art, I I I ; Kouroi, I I I ; Engraved Gems of the Romans, 230

Rickman, G. E., Roman Granaries and Store Buildings, 235

Rosenmeyer, Thomas G., The Green Cabinet, 104

Rossiter, Stuart, Rome and Environs, 235

Schweitzer, Bernhard, Greek Geometric Art, 230

Scullard, H. H. (ed.), The Oxford Classical Dictionary, I 10 
Skelton, Robin, Two Hundred Poems from the Greek Anthology, 224

Snowden, Frank M., Blacks in Antiquity, II 3

Starr, Chester, The Ancient Greeks, 227

Syme, Sir Ronald, Ten Studies in Tacitus, 108

Tölle, Renate, Die antike Stadt Samos, I ro

Toynbee, J. M. C., Death and Burial in the Roman World, 234

Tripp, Edward, Handbook of Classical Mythology, 234

Trump, David, Dictionary of Archaeology, III

Viansino, Giovanni, Introduzione allo studio critico della letteratura latina, 226

Walcot, Peter, Greek Peasants Ancient and Modern, II 3

Walsh, P. G., The Roman Novel, 225

White, K. D., Roman Farming, 108; Bibliography of Roman Agriculture, 235

Whittaker, C. R., Herodian, 229

Wild, J. P., Textile Manufacture in the Northern Roman Provinces, I I I

Wilson, B. W. J. G., Res Publica, 107

Witt, R. E., Isis in the Graeco-Roman World, 233

Zazoff, Peter, Etruskische Skarabäen, I Iо 